\title{
AMERICAN INTERVENTION IN HAITI
}

Referring to previous editorial comments in this JourNal and in particular to the editorial entitled International Responsibility in Haiti and Santo Domingo in the July issue of the present year, it is of special interest to note the conclusions of the Select Committee on Haiti and the Domini can Republic appointed by the United States Senate. ${ }^{1}$ Because of the negotiations under way looking to the early termination of military government in Santo Domingo this report deals only with the situation in Haiti.

It should be recalled that these findings are the result of the most conscientious investigation both in the Island of Santo Domingo and in Washington. The committee welcomed the testimony and the free expression of the views of all persons believed to be cognizant of conditions in the two republics. It also gave due weight to the evidence and opinions of persons who because of popular passions and prejudice in these countries did not dare to speak freely in the open hearings of the committee.

It is essential, furthermore, to emphasize the fact that this report is of a strictly non-partisan character-the conclusions of Republicans and Democrats concerning the original act of intervention by the Administration of President Wilson in 1915, and the subsequent acts of the Administration of President Harding. Under such circumstances there was ample opportunity for prejudiced opinions and inclinations to support the serious charges brought against the United States by American citizens of repute because of the original act of intervention and subsequent alleged abuses of administration and prolonged occupation.

A further fact worthy of notice is that the committee reveals the utmost candor in admitting certain abuses, and notably in recognizing that: "The American representatives in the opinion of your committee influenced the majority of the Assembly (of Haiti) in the choice of a president. Later, they exercised pressure to induce the ratification by Haiti of the convention in September, 1915, precisely as the United States had exercised pressure to induce the incorporation of the Platt Amendment in the Cuban Constitution, thus to assure the tranquility and prosperity of Cuba." (Page 7.)

Inasmuch as this openly avowed constraint of the Haitian officials by the American Government has been the subject of bitter comment by reputable American citizens, it is imperative to call attention to the reasons for the original intervention and the policy adopted by the United States. The statements of the committee on these points deserve to be quoted:

In brief, before American intervention there had been no popular representative or stable government in Haiti. The public finances were in disarray, public credit was exhausted, and the public revenues were wasted or stolen. Highways and agriculture had given way to the jungle. The people, most of whom lived in wretched poverty,

${ }^{1}$ See Report No. 794, 67th Cong., 2d Sess. 
were illiterate and spoke no other language than the native Creole. The country and its inhabitants have been a prey to chronic revolutionary disorders, banditry, and even during periods of comparative peace, to such oppressive and capricious governors that the great mass of the people who, under happier circumstances might have become prosperous peasant farmers, have had neither opportunity nor incentive to labor, to save, or to learn. They had no security for their property and little for their lives. Voodoo practices, of course, were general throughout the territory of the Republic. (Page 5.)

Testimony taken by the committee shows how the chronic anarchy into which Haiti had fallen, the exhaustion of its credit, the threatened intervention of the German Government and the actual landing of the French naval forces, all imperiled the Monroe Doctrine and lead the Government of the United States to take successive steps set forth in the testimony, to establish order in Haiti to help to institute a government as nearly representative as might be, and to assure the collaboration of the Governments of the United States and Haiti for the future maintenance of peace and the development of the Haitian people. (Page 7.)

Viewed in the light of these grounds for intervention and of the purpose of the United States to establish guarantees of order and prosperity, it is apparent that a certain measure of constraint on Haitian officials was logical and imperative. It would have been stultifying had the American Government permitted the officials of Haiti to perpetuate the very conditions which occasioned the intervention. The people of Haiti through their representatives were properly required to adopt certain measures which the United States believed essential for the achievement of its beneficent and altruistic policy. To protest against violations of representative government, of the sovereignty, independence and equality of a sister republic is to ignore the facts and the logic of the situation. Such protests would seem to imply that there is no international responsibility on the part of more fortunate nations towards those peoples who become the victims of bad government and of progressive anarchy. This extraordinary point of view amounts virtually to the cynical dogma that "every nation should be permitted to go to the Devil in its own way." It is a point of view fortunately held by but few extremists and has been effectively refuted by the candid, courageous report of the Senate Committee.

Concerning the results attained under American occupation, with due allowance for the mistakes and abuses of incompetent or criminal officials, the committee claims that:

Peace, sure and undisturbed peace, has been established throughout Haiti for the first time in generations. . . . Today, as old travelers will bear witness, for the first time in generations the men have come down freely from their hidden huts to the trails and to the towns. 
Although the Haitian Government has declined to employ American experts in the administration of internal revenue, nevertheless, under the insistence of the financial advisor and despite general business depression, the sum of internal revenue collected has increased threefold, although the internal revenue laws are unchanged. (Page 8.)

During the last three years $\$ 5,000,000$ of interest and principal have been paid. Today there is no interest or capital overdue. The foreign debt has been reduced by one-third. On the contrary, there is a surplus in the treasury and it is proposed to refund the outstanding debt to the great benefit of the Haitian tax-payer. (Page 9.)

The confidence placed in the Americans by the Haitian peasants and the approval frequently communicated to the committee by those who know and sympathize with the peasants and who are engaged in philanthropic or educational work among them negative the idea of any campaign of terrorism against the inhabitants such as agitators and professional propagandists, Haitian and American, would have appear. (Page 23.)

It may be set down to the credit of the American occupation and the treaty officials that the Haitian cities, once foul and insanitary, are now clean, with well-kept and well-lighted streets. The greater part of an arterial highway system opening up the heart of the country has been built. The currency, which once violently fluctuated under the manipulations of European merchants, has been stabilized, to the great advantage of the Haitian peasant. Arrears of amortization as well as of interest on the public debt have been paid, as also are regularly paid the salaries of the smallest officials. The steamship communications between Haiti and the United States are greatly improved. Trade and revenues are increasing. The revision of the customs and internal taxes, so important in the prosperity of Haiti and especially of its poorest classes, awaits the funding of the debt by a new loan. There is peace and security of property and person throughout the Republic. The peasant in his hovel or on the road to market is safe from molestation by brigand or official authority. A force of 2,500 gendarmes, insufficiently trained to cope with the caco outbreak in 1918, is now admirably disciplined. As its morale has improved, the force has become at once considerate and more efficient in the discharge of its duties. It is noteworthy that an increasing proportion of the commissioned officers are native Haitians, those promoted from the ranks to be supplemented by others, graduates of the newly established cadet school. In brief, under the treaty, the peace of the Republic, the solvency of its Government, and the security of its people have been established for the first time in many years. (Page 24.)

This, it must be conceded, is a fine record of accomplishment, and yet the Senate Committee "submits that the American people will not consider their duty under the treaty discharged, if, in addition to what has been accomplished, there are not placed within the reach of the Haitian masses, justice, schools, and agricultural instruction. The treaty itself makes no provision to consummate these things." (Page 24). 
The committee in no way suggests the desirability or the possibility of an immediate withdrawal of American forces and officials from Haiti. It urges the appointment of a commission "comprising a commercial advisor, an expert in tropical agriculture, and an educator of the standing and special experience of Doctor Moton" for the purpose of making "a survey of the need and opportunity for industrial and especially of agricultural instruction and development in a country which depends upon agriculture as its sole source of wealth." The committee believes that: "As wealth and revenues increase, schools, trails, and highways may be extended and as they are extended, in turn, the revenues will be further enhanced and so enable the further development of the public services."

The committee favors the abolition of military tribunals for the trial of natives accused of offences against public order or attacks upon the military and peace forces within the republic, but points out that "their abolition is conditioned upon certain precedent steps, among them a reform of the courts of first instance."

A significant recommendation of the committee is that the Haitian Government should restrict the great land holdings by foreign interests. This would seem to afford the logical answer to those violent critics of the policy of the United States Government in insisting on the change in the Haitian Constitution to permit the ownership of land by foreigners.

The committee complains with justice against the frequent changes in the personnel of the Latin American Bureau in the Department of State in Washington and of other officials charged with the supervision and execution of the policy of the American Government in Haiti. It insists that "there can be a rapid development in Haiti, moral, social, political, and economic, provided always that American policy be marked by continuity and by the spirit of service."

The report closes with these solemn words:

There are certain elements in Haiti which can balk and perhaps delay the rehabilitation of the country. They cannot prevent it. They can do much to further it. The obvious duty of patriotic Haitians is to uphold their own Government in effectively cooperating with that of the United States under the treaty, and so hasten the day when Haiti may stand alone. The alternative to the course herein suggested is the immediate withdrawal of American support and the abandonment of the Haitian people to chronic revolution, anarchy, barbarism, and ruin.

In the light of all the facts and in spite of acknowledged blunders, it would seem clear that the United States is under a moral mandate to assist in the rehabilitation of this unhappy republic and should not be diverted from its lofty mission by any base imputations against its original intervention or prolonged occupation.

Philip Marshall Brown. 